\section{Did You Know?}

It's not just your parent or your grandparent whose hearing may be slipping. A 25-year-old farmer can have the ears of 50-year-old and not even know it!

- Nothing can restore lost hearing. Once it's gone, it's gone!

n BUT hearing loss caused by noise is preventable - and you can choose to prevent it.

- Noise-induced hearing loss can result from working around farm noise - even hand drills - without hearing protection.

- If you're exposed to loud noise on the farm you may already be losing your hearing.

- Hearing protection can increase your ability to hear your equipment or others' voices because it cuts down on the background noise. Some earmuffs have amplification circuits that may help even hearing impaired workers communicate better in noisy backgrounds.

- You can buy protective earmuffs with built-in radios that allow you to listen safely to your favorite sports or music while working. They make nice gifts.

- People have found that protecting themselves from noise reduces their stress, anxiety and fatigue at the end of the day.

- The best way to avoid hearing loss is to reduce your exposure by using quieter equipment or staying away from noise.
Sound Advice: Protect Your Ears from Damaging Noise

Exposure to noise above 85 decibels (dB)

can cause permanent hearing loss.

It can even result from a single nearby shotgun blast, dynamite blast or other very loud noise.

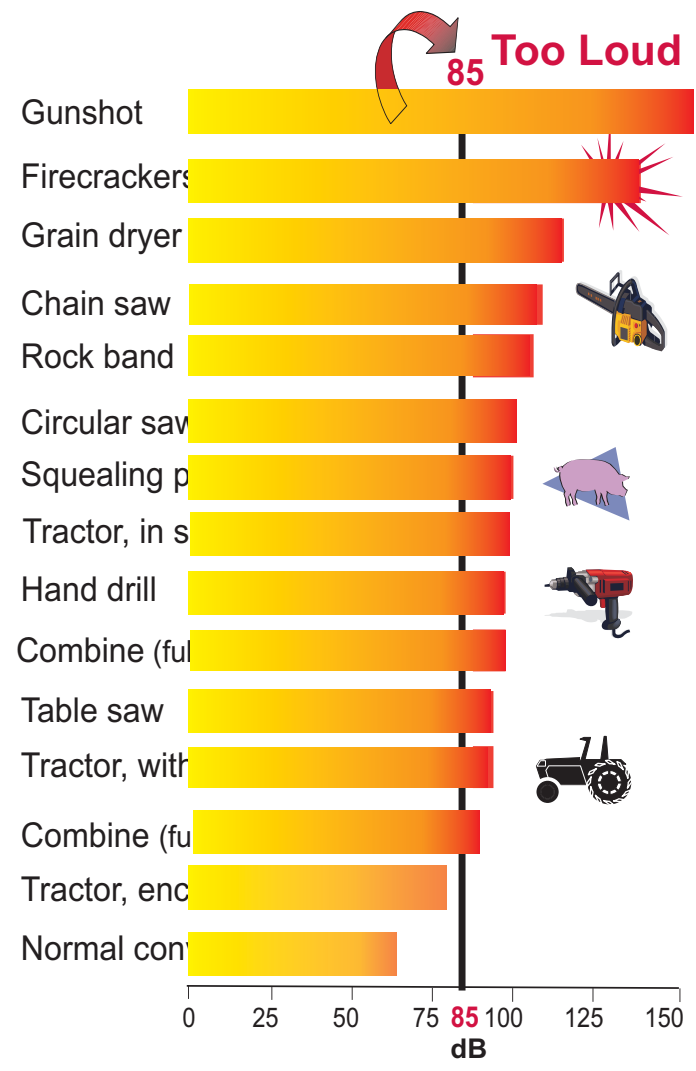

A "decibel" is the unit used to measure the loudness of sound

If you need to raise your voice to be heard an arm's length away, the noise is probably loud enough to damage your hearing.

\section{How Long Is Too Long?}

The red bar below shows how long it takes for a particular sound level to become dangerous to the human ear. For example, a chain saw has a sound intensity of about $109 \mathrm{~dB}$. Without proper hearing protection, running a chain saw for only 2 minutes can cause hearing loss!

It only takes..

\section{$112 \mathrm{~dB} \mid<1 \mathrm{~min}$}

$109 \mathrm{~dB} \mid<2 \mathrm{~min}$

$106 \mathrm{~dB} \mid<4 \mathrm{~min}$

\begin{tabular}{ll|l}
$103 \mathrm{~dB}$ & $7.5 \mathrm{~min}$ \\
\hline
\end{tabular}

\begin{tabular}{ll}
$100 \mathrm{~dB}$ & $15 \mathrm{~min}$ \\
\hline
\end{tabular}

$97 \mathrm{~dB}-30 \mathrm{~min}$

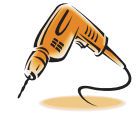

$94 \mathrm{~dB}-1$ hour

$91 \mathrm{~dB}$

$88 \mathrm{~dB}$

2 hou

$85 \mathrm{~dB}$

8 hours

If you know someone with hearing loss, you know that conversation can be frustrating for both of you.

A good hearing aid can help, because it amplifies the sound. However it does not make sound clearer the way glasses make your vision sharp.

$$
\text { Hearing aids do not correct hearing }
$$
the way glasses correct vision.

\section{What's That Ringing?}

Have you ever driven an open cab tractor for several hours or gone to a loud concert, then heard a ringing in your ears for the next hour or two? How would you feel if that ringing never went away?

That's what happens to many people exposed to loud noise.

That ringing in the ears is called tinnitus, and while many people hear ringing, some hear hissing, roaring, whistling, chirping or clicking sounds. Tinnitus may show up before you even notice much hearing loss.

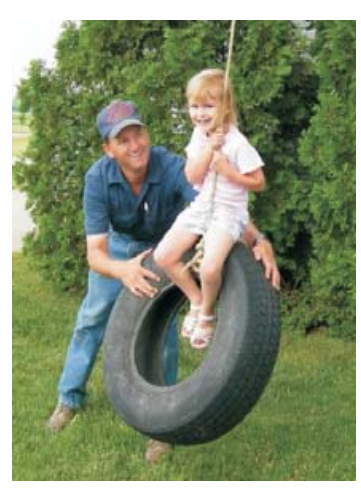

'My little girl doesn't understand why I can't hear what she is whispering in my ear. She says... 'Mommy hears me when I whisper'.'

"I thought if I lost m hearing, it would be quiet. But that constant ringing keeps me awake at night and I can't hear my friends very well on my cell phone.

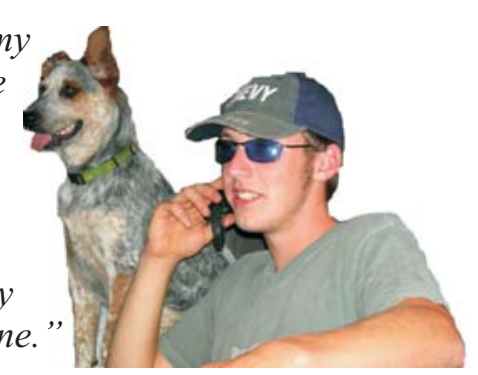




\section{Hearing Protection Resources}

Centers for Disease Control and Prevention, National Institute for Occupational Safety and Health, Noise and Hearing Loss Prevention Resources include this brochure at:

www.cdc.gov/niosh/topics/noise

National Hearing Conservation Association www.hearingconservation.org

National Agricultural Safety Database

Hearing Conservation:

www.cdc.gov/nasd/menu/topic/hearing.html

National Institutes of Health WISE EARS! Campaign Resources: www.nidcd.nih/gov/health/wise/index.asp

Dangerous Decibels: www.dangerousdecibels.org

University of Kentucky Agricultural Disability Awareness and

Risk Education (AgDARE) NIHL Resources:
www.mc.uky.edu/scahip/projects/agdare-2.htm

American Tinnitus Association: www.ata.org

Hearing Education and Awareness for Rockers (a non-profit group that educates young people about the dangers of exposure to loud music): www.hearnet.com

\section{Acknowledgments}

Writer/Editor: Barbara Mulhern, Agricultural Journalist and NIOSH Great Lakes Center for Agricultural Safety and Health: Deborah Reed, University of Kentucky; Sam Steel, Pennsylvania

For additional copies, questions, or comments related to this brochure, e-mail farm.noise@ecdc.gov

To receive other NIOSH documents or for more information about occupational safety and health topics, contact:

1-800-CDC-INFO (1-800-232-4636)

TTY: $1-888-232-6348$

E-mail: cdcinfo@cdc.gov
or visit the NIOSH Web site at www.cdc.gov/niosh.

For a monthly update on news at NIOSH, subscribe to

DHHS-(NIOSH) Publication No. 2007-175

DEPARTMENT OF HEALTH AND HUMAN SERVICES Centers for Disease Control and Prevention
National Institute for Occupational Safety and Health

SAFER • HEALTHIER P PEOPLE ${ }^{\text {TM }}$

\section{How Can I Protect My Hearing?}

You don't have to have the hearing of a 50 year old by the time you're 25. It's up to you to protect your hearing!

- Identify noisy tasks around your farm and shop that may be harmful to your hearing.

- Wear hearing protection at all times whenever you are exposed to loud noise.

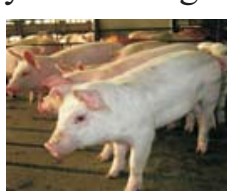

- Make hearing protection convenient. Stash earplugs in your pockets every morning when you grab your cell phone and keys. Hang canal caps or muffs on your tractor steering wheel, combine and lawn mower.

- Reduce equipment noise by replacing worn, loose or unbalanced machine parts. Keep equipment well lubricated and maintained. If you have been meaning to replace that loud tractor muffler, do it now.

- Limit your exposure to loud noise. Stay away from noisy equipment if you don't need to be near it. Keep cab doors and windows closed.

- Have your hearing tested by a health care provider if you or someone else suspects a problem. Your family or friends may be the first to notice that your hearing is slipping.

- Keep children away from noisy areas and equipment

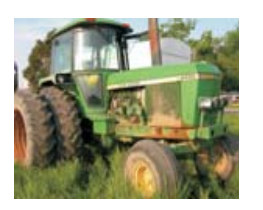

The best protectors are the ones you will wear all the time you are around loud noise. noise.
Formable Earplugs Premolded Earplugs

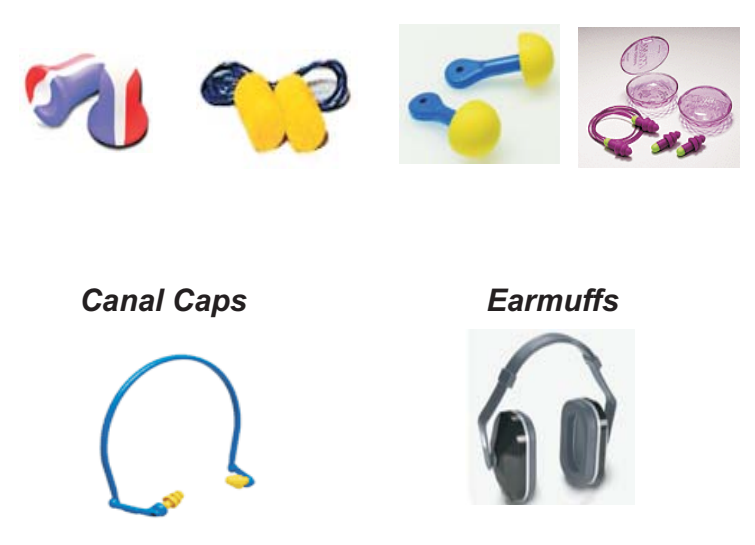

There are hundreds of different styles of hearing protectors to choose from today. Everyone can find one that is convenient, easy to use, comfortable and fits his or her budget. "Hunter's" or "shooter's" muffs may work well for you. Hearing protectors are available on the internet and in local home improvement and farm stores.

Only trust your ears to products designed as Cother makeshift protectors can let noise pass right through.

“Getting used to wearing my earplugs was like getting used to my favorite bootseven after getting a good fit,
it still took a little time."
They're your ears

\section{Protect them}

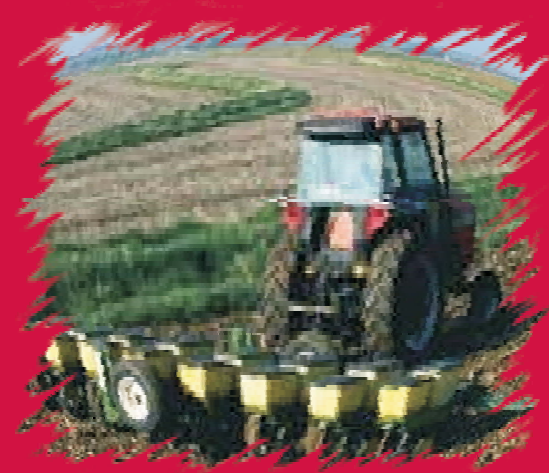

Hearing Loss Caused by Farm Noise is Preventable

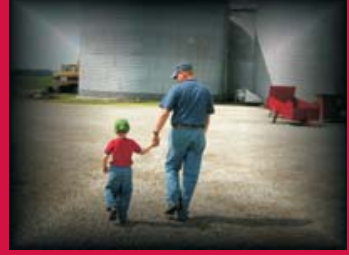

